\title{
Action of metoclopramide on gastric emptying and small bowel transit time
}

\author{
W. B. JAMES AND R. HUME \\ From the Southern General Hospital, Glasgow
}

Metoclopramide hydrochloride belongs to the orthopramide series of drugs and is characterized chemically as 4-amino-5-chloro-N-(2-(diethylamino) ethyl)-o-anisamide dihydrochloride hydrate.<smiles>CCN(CC)CCNC(=O)c1cc(Cl)c(N)cc1OC</smiles>

Studies on animals and in man indicate that metoclopramide increases the gastric emptying rate, has a potent antiemetic effect, and is virtually free of side effects (Boisson and Albot, 1966). A substance with such attributes would obviously be very useful in clinical radiology.

A preliminary study made on 95 consecutive patients referred for barium meal examination supported these findings. Of 47 patients who received $20 \mathrm{mg}$ metoclopramide intravenously, 18 showed complete gastric emptying in one hour and in 32 the barium had reached the caecum in one hour, while of the remaining 48 who did not receive this substance only one showed complete gastric emptying at one hour and in only six did the barium reach the caecum in this time. These results were sufficiently encouraging to merit confirmation by double blind trial. Observations were also made on the antiemetic effect of metoclopramide in a group of patients undergoing intravenous cholangiography.

\section{MATERIALS AND METHODS}

PATIENTS Fifty-four consecutive patients referred for barium meal examination took part in the double blind trial. Four patients who had had previous gastric surgery were excluded from the trial, leaving a total of 50 .

The patients were randomly allocated into two groups: those to receive metoclopramide and those to receive a placebo. There were 25 patients in the metoclopramide group (11 men and 14 women) whose ages ranged from 19 to 72 years with a mean of 52.1 years. There were 25 patients in the placebo group (14 men and 11 women) whose ages ranged from 21 to 72 years with a mean of $50 \cdot 1$ years.

The radiological diagnosis of the patients in each group is summarized in Table $\mathbf{I}$.

PROCEDURE Each patient had a barium meal examination carried out by one of us (W.B.J.) according to a standard procedure during which the patient drank $250 \mathrm{ml}$ of barium sulphate suspension. After initial assessment either the placebo or $20 \mathrm{mg}$ metoclopramide (made up in identical ampoules) was injected intravenously. Neither the patient nor W.B.J. knew the identity of the injected material. The patient was told that the injection was being given in order to accelerate the transit of barium through the bowel. Follow-through films of the abdomen were obtained at one hour and one and a half hours after the ingestion of barium. These follow-through radiographs were then read 'blind' by one of us (W.B.J.). The reason for choosing complete gastric emptying as the point of reference was because of the difficulty in establishing any lesser degree of emptying. The identity of the ampoules was not revealed until after all of the radiographs had been read. The number of patients in whom the stomach was completely empty at one hour and at one and a half hours, and the number in each group in whom the barium had reached the caecum or beyond at one hour, was recorded.

\section{RESULTS}

The results are set out in Table II.

TABLE I

\begin{tabular}{lllllll} 
Group & Total No. & Normal & $\begin{array}{l}\text { Duodenal } \\
\text { Ulcer }\end{array}$ & $\begin{array}{l}\text { Gastric } \\
\text { Ulcer }\end{array}$ & $\begin{array}{l}\text { Hiatus } \\
\text { Hernia }\end{array}$ & $\begin{array}{c}\text { Duodenal } \\
\text { Neoplasm }\end{array}$ \\
\hline Placebo & 25 & 10 & 10 & 4 & 1 & -1 \\
Metoclopramide & 25 & 11 & 11 & 2 & -1
\end{tabular}


TABLE II

DIFFERENCE IN GASTRIC EMPTYING AND SMALL BOWEL TRANSIT TIME BETWEEN THE TWO GROUPS

\begin{tabular}{|c|c|c|}
\hline Group & Number & $\begin{array}{l}\text { No. of Stomachs } \\
\text { Empty at }\end{array}$ \\
\hline & & 1 Hour $1 \frac{1}{2}$ Hour \\
\hline
\end{tabular}

$\left.\begin{array}{lllrr}\hline \text { Placebo } & \begin{array}{l}14 \text { males } \\ 11 \text { females }\end{array} \\ \text { Metoclopramide } & \begin{array}{l}11 \text { males } \\ 14 \text { females }\end{array}\end{array}\right\} \begin{array}{rrrr}25 & 6 & 15 & 16\end{array}$

At one hour there was no significant difference between the number of empty stomachs in the two groups $\left(\chi^{2}=2.381 ; P>0.05\right)$. At one and a half hours there was a significant increase in the number of empty stomachs in the metoclopramide group $\left(\chi^{2}=5 \cdot 1946 ; P<0.05\right)$. There was a highly significant increase in the number of patients in the metoclopramide group in whom the barium had reached the caecum or beyond at one hour $\left(\chi^{2}=17.0138\right.$; $\mathbf{P}<0.001)$.

SIDE EFFECTS One hundred and forty-two patients have now had $20 \mathrm{mg}$ metoclopramide administered intravenously. Each patient was kept under observation for a minimum of three hours afterwards. None of the patients who received the placebo in the double blind trial complained of any ill effect. One patient who had had metoclopramide complained of a feeling of sleepiness which occurred aproximately one hour after injection. Two metoclopramide patients vomited within two to three minutes after the injection. Both had been referred for the investigation of vomiting. Conversely two other patients referred because of vomiting improved considerably after injection of metoclopramide. Four patients who felt nauseated after ingestion of a little barium claimed to feel better after intravenous metoclopramide. Despite the decrease in small bowel transit time after metoclopramide injection, no patient complained of subsequent diarrhoea.

\section{DISCUSSION}

This investigation has shown that there is a statistically significant increase in the rate of evacuation of barium from the stomach, and a highly significant increase in the rate of progression of barium through the small bowel after intravenous administration of $20 \mathrm{mg}$ of metoclopramide. These findings are in agreement with a similar double blind study carried out by Margieson, Sorby, and Williams (1966). Our observations during fluoroscopy suggest that the rapid gastric emptying is due to increased contractile activity in the stomach, manifested at barium meal examination by an increase in both the number and depth of peristaltic waves in the stomach, which is accompanied by marked dilatation of the pylorus and duodenum. Very rapid movement of barium has been observed in the proximal jejunum. This has usually been associated with active gastric peristalsis and 'pumping' of barium through the pylorus, and it may be that this pumping action is in itself sufficient to explain the rapid progress of barium through the small bowel. The advantages of such a substance, virtually free of side effects, in diagnosis in radiology is easily appreciated. The examination of the small bowel is completed in a much shorter time, normally within one and a half hours, and often in less than one hour from the commencement of the examination. Because of the rapid and uniform filling of the small bowel fewer radiographs have been necessary, so that the radiation dose has been decreased. In most patients with gastric atony or with pylorospasm metoclopramide given intravenously has initiated gastric emptying within a few minutes of injection, thus saving the time of both patient and radiologist. It is possible that the ability to increase gastric peristalsis at will by such a simple and safe procedure may lead to greater precision in the diagnosis of gastric neoplasm.

With regard to the antiemetic effect of metoclopramide, a double blind trial was carried out in 60 patients who had received Biligrafin Forte during intravenous cholangiography. This injection is followed in a large number of patients by retching and vomiting (Wax and Crummy, 1966; Darnborough and Geffen, 1966). Metoclopramide, $20 \mathrm{mg}$, was compared with normal saline and $50 \mathrm{mg}$ of Largactil, each substance being administered intramuscularly. The number of patients in each group who vomited was similar $(P>0.05)$. These results indicate that neither metoclopramide nor Largactil in the doses given was effective in reducing the incidence of vomiting following the injection of Biligrafin Forte.

\section{SUMMARY}

This investigation confirms that the drug metoclopramide promotes gastric emptying and accelerates the transit of barium through the small bowel. The implications of these actions in diagnostic radiology are discussed.

We wish to record our gratitude to the late Dr. A. G. Melrose for his help in the earlier part of this investigation and to thank all the physicians and surgeons who allowed us to include their patients in the investigation.

Dr. Michael F. Grayson of Merck, Sharp and Dohme, kindly arranged the supply of metoclopramide and placebo. 


\section{REFERENCES}

Boisson, J., and Albot, G. (1966). Sur l'intérêt thérapeutique du métoclopramide. A propos de 2,300 observations. Revue critique et indications de son emploi. Cah. Coll. Méd. Hôp. Paris, 7, 45-63.
Darnborough, A., and Geffen, N. (1966). Drip infusion cholangiography. Brit.J. Radiol., 39, 827-832.

Margieson, G. R., Sorby, W. A., and Williams, H. B. L. (1966). The action of 'Metoclopramide' on gastric emptying: a radiological assessment. Med.J. Aust., 2, 1272-1274.

Wax, R. E., and Crummy, A. B. (1966). Drip infusion cholangiography. Radiology, 87, 354

\section{The February 1968 Issue}

\section{THE FEBRUARY 1968 ISSUE CONTAINS THE FOLLOWING PAPERS}

\section{Signposts}

Experimental cholelithiasis J. W. FRESTON and I. A. D. BOUCHIER

Carbenoxolone sodium M. J. S. LANGMAN

Crohn's disease of the colon and its distinction from diverticulitis G. T. SCHMIDT, J. E. LENNARD-JONES, B. C. MORSON, and A. C. YOUNG

Diseases associated with ulcerative colitis and Crohn's disease BARBARA HAMMER, PAMELA ASHURST, and J. NAISH

Degradation of bile salts by human intestinal bacteria M. J. HILL and B. S. DRASAR

Ready absorption of medium chain triglyceride in the steatorrhoea syndrome B. J. SMITS, P. WILDING, and w. T. COOKE

Histological and functional study of gastric mucosa in tropical sprue H. G. DESAI, A. V. BORKAR, and K. N. JEEJEEBHOY

Effect of patterns of eating and antacids on faecal urobilinogen excretion S. L. MALHOTRA

Treatment of gastric ulcer with carbenoxolone: antagonistic effect of spironolactone RICHARD DOLL, M. J. S. LANGMAN, and H. H. SHAWDON

Treatment of gastric ulcer with oestrogens RICHARD DOLL, M. J. S. LANGMAN, and H. H. SHAWDON

Some experience with deglycyrrhizinated liquorice in the treatment of gastric and duodenal ulcers with special reference to its spasmolytic effect S. N. TEWARI and E. C. TREMBALOWICZ

Effect of oesophageal perfusion with acid on basal gastric secretion G. R. GILES, C. G. CLARK, and R. BUCHAN

Clinical data and characteristics differentiating types of peptic ulcer K. T. VESELÝ, Z. KUBÍČKOVÁ, and M. DVOŘ́́KOVÁ with the statistical assistance of K. ZVOLÁNKOVÁ
Comparative study of operated cases of peptic ulcer in Madras in the 1940s and 1960s N. MADANAGOPALAN, R. SUBRAMANIAM, and M. N. KRISHNAN

Studies of the epidemiology of peptic ulcer in a rural community: prevalence and natural history of dyspepsia and peptic ulcer R. DEANS WEIR and E. MAURICE BACKETT

Treatment of chronic constipation with lactulose syrup: results of a double-blind study A. WESSELIUS-DE CASPARIS, S. BRAADBAART, G. E. v.d. BERGH-BOHLKEN, and $M$. MIMICA

Effect of vagotomy upon the small intestine J. BEJAR, $\mathbf{s}$. A. BROITMAN, and N. ZAMCHECK

Effect of intravenous iron therapy on gastric acid secretion in iron-deficiency anaemia H. G. DESAI, B. C. MEHTA, A. V. BORKAR, and K. N. JEEJEEBHOY

Alkaline phosphatase levels in normal and diseased small bowel ANNE FERGUSON, W. C. WATSON, J. D. MAXWELL, and G. S. FELL

Gastric secretory response to iron therapy w. D. STONE

Rectal and colonic mucosal biopsy findings and faeces, sigmoidoscopy, and histopathological correlation in amoebiasis and other colitis N. MADANAGOPALAN, S. P. VEDACHALAM, R. SUBRAMANIAM, and R. G. MURUGESAN

Effect of a synthetic gastrin-like pentapeptide upon the intestinal transport of sodium, potassium, and water $\mathbf{J}$. C. GINGELL, M. W. DAVIES, and R. SHIELDS

Gastric cancer associated with gastroenterostomy and partial gastrectomy F. PYGOTT and V. L. SHAH

Use of 2 deoxy-D-glucose to test for the completeness of surgical vagotomy D. G. THOMAS and H. L. DUTHIE

A fistula for measurement of bile flow and composition in the dog D. M. FLETCHER and R. L. CORRY

Notes and activities

Copies are still available and may be obtained from the PUBLISHING MANAGER, BRITISH MEDICAL ASSOCIATION, TAVISTOCK SQUARE, W.C.1, price 18s. 6D. 